\title{
ТЕКСТОВИЙ ПОРТРЕТ ЕМОЦІЇ РАДОСТІ (на матеріалі оповідання Б. Рейман «Die Geschwister»)
}

У статті розглянуто особливості семантики емоиії радості, вербалізованої сучасною німецькою мовою в тканині художнього твору жанру оповідання. Уточнено поняттєво-теоретичний апарат, зокрема поняття 'емотивна ситуація', терміни 'емоція' і 'радість', виявлено два різновиди емотивних ситуацій, висвітлено позитивний, нейтральний і негативний плани останніх, схарактеризовано суб'єктів - носіїв емоції радості, виокремлено основні каузатори емоціі радості, запропоновано класифікацію мовних одиниць-маркерів зі значенням 'емоція радості, ії варіанти'.

Ключові слова: емоція, радість, емотивна ситуація, маркери, каузатор.

Romanova N. Text Portrait of the Emotion of Joy (Based on B. Riemann's Story "Die Geschwister"). The peculiarities of the semantics of joy as an emotion, verbalized by the modern German language in such genre as narration, have been studied in the article. Being an active participant in various life situations, a person expresses an emotional and evaluative attitude to them, the word around and other people, which we find through the modality of experience, their depth, duration, intensity. Psychologists interpret the emotion of joy more as a positive emotion, considering it contagious, as well as fear. The expression of emotion of joy correlates with physiological, physical, intellectual, spiritual, socio-psychological, cultural, aesthetic and other needs in the background of the assessment of what a person needs. Heredity, age, gender, upbringing, etc. can also influence the emergence of the emotion of joy. According to the plot, not all characters experience the emotion of joy with equal force. For instance, senior lieutenant Vasyl Ivanovych, native Ukrainian, has guests in a 'stranger's apartment' every night and dances hopak, while the Elizabeth's father Arendt, having returned from Soviet captivity, cries with joy; his daughter rejoices at her brother's marriage but at the same time is jealous of his future wife. Her brothers often laugh at the illogicality and causticity of their sister's thoughts, and so on. In this context, the study of both motivation and semantics of the phenomenon is relevant. The purpose of the proposed study is to reconstruct a text portrait of the emotion of joy. Among the tasks we distinguish the following: firstly, the clarification of the concepts of 'emotional situation', 'emotion', 'joy'; secondly, the characteristics of the subjects of the emotion of joy; thirdly, the establishment of source of the emotion of joy; fourthly, the classification of language units with the meaning of 'joy and its variations'. It is revealed that the text portrait of the emotion of joy is the result of mental and aesthetic activity. It is based on implicit and explicit emotional situations. The variability of the semantic content of the latter is established, the classifications of a) subjects (carriers of the emotion of joy), b) linguistic means are proposed.

Key words: emotion, joy, emotional situation, markers, mechanism, causator. 


\section{Вступ}

Дослідження емоцій у різних типах текстів не лише актуальні, але й важливі для реалізації ефективної комунікації (Филимонова, 2007: 108). Лінгвісти здійснюють аналіз фрагментів і цілих текстів (van Dijik, 1977). Під фрагментом розуміють «абзац чи кілька абзаців, об’єднаних розвитком однієї теми, пов'язаних лексичними або граматичними засобами», або мікротему, «що входить у загальну тему, відображену в тексті» (Пентилюк, 2009: 41). Текст тлумачать із традиційних і 'нетрадиційних’ позицій (Єщенко, 2009: 9). Традиційне визначення тексту орієнтує на лінійну послідовність мовних одиниць, семантичну зв'язність, змістову цілісність та завершеність (Гальперин, 1981: 18), 'нетрадиційне' звужує обсяг поняття до речення, або розширює його до метатексту як сукупності всіх творів одного автора (Лотман, 1998: 22).

Для нашого аналізу релевантними є фрагменти й текст у традиційному розумінні, оскільки їхній автор не дистанціюється від зображуваного, а намагається продемонструвати своє емоційно-оцінне ставлення до подій, явищ, предметів тощо. При цьому утворюється певний психологічний простір за формулою 'автор - персонаж’. Психологічна єдність автора й персонажа дають змогу розгорнутися тій чи тій емоції або емоційному патерну.

Загалом емоції забарвлюють земне буття, його смисл та керують індивідом щодо адаптації в навколишньому світі (Романова, 2020: 107-113).

Кодифікація емоцій на сьогодні через специфічність й інтимність характеристики психічного лишається відкритою (Кириленко, 2007: 9). Крім того, кількість ознак емоцій змінюється з віком людини, залежить від ії культурного розвитку (там само: 10), темпераменту, вольових процесів, почуттів, соціально-психологічного досвіду, соціальних установок тощо (Орбан-Лембрик, 2004). Звідси, очевидно, й особлива дослідницька увага та зацікавленість науковців до об’єкта.

Безперечно, уже існують певні напрацювання таких лінгвістів, як-от: Ю. Д. Апресяна, Л. Р. Безуглої, Н. І. Бойко, В. Г. Гака, М. В. Гамзюка, А. П. Мартинюк, Г. І. Приходько, В. І. Шаховського, І. С. Шевченко та ін.

Огляд праць цих та інших мовознавців свідчить про те, що текстовий портрет емоції радості ще не був предметом спеціального наукового пошуку. 
Важливість вибору предмета вивчення вбачаємо й у загальній спрямованості сучасної германістики на розгляд семантики художнього тексту в площині ментальних і психічних процесів, що дає змогу уточнити характер взаємодії між мовою та мисленням, між мовленням й емоціями, між мовленнєвою діяльністю та етнічною культурою, простежити рівень співвідношення між мовою художньої літератури й повсякденним мовленням.

Метою нашого дослідження є реконструкція текстового портрета емоції радості. Відповідно до поставленої мети необхідно розв’язати такі завдання: 1) уточнити поняття 'емотивна ситуація', 'емоція', 'радість’; 2) схарактеризувати суб’єктів - носіїв емоції радості, 3) виявити причини появи емоції радості; 4) класифікувати мовні одиниці зі значенням 'радість і ії варіанти'.

\section{Методи дослідження}

Одержані в процесі дослідження відомості про емоцію радості, іiі об'єктивацію в художньому творі грунтуються на використанні низки загальнонаукових і спеціальних лінгвістичних методів. До прикладу, вибирання емотивних ситуацій та елементів, що позначають феномен, здійснено гіпотетико-дедуктивним методом, характеристику суб'єктів - носіїв емоції радості - з'ясовано через опис і контекстуально-інтерпретаційний аналіз. За допомогою структурно-семантичного аналізу виявлено лінгвістичні засоби реалізації емоції радості і іiі варіантів, шляхом застосування прийому тематичних груп виділено сукупність мовних одиниць, пов'язаних спільною темою 'емоція радості'. Для інтерпретації інтенсивності вияву емоції радості було залучено елементи концептуального аналізу.

\section{Виклад основного матеріалу}

Емотивна ситуація - сукупність умов і обставин, що викликають у її учасника/-ів i/або споглядача/-ів певні емоції. Емоцію трактуватимемо в річищі диференціальної теорії, запропонованої К. Е. Ізардом, як складний процес, що містить у собі три компоненти: нейрофізіологічний, моторно-експресивний і чуттєвий (Изард, 2008: 69).

Радість належить до позитивних базових емоцій. Її основні ознаки: усмішка, сміх, психологічний комфорт, благополуччя, відчуття легкості й свободи, енергії і сили. Ця емоція репрезентує співпричетність 
людини до світу, їі впевненість у собі, захоплення буттям і лінгвоспільнотою. Цей феномен, як й інші емоції, рідко виникає відокремлено, тобто в 'чистому вигляді'; може тісно взаємодіяти з емоціями інтересу, сорому, презирства, а також з перцептивно-когнітивними процесами й поведінкою; спонтанна, пов'язана зі значущими для індивіда досягненнями, перемогою над самим собою; переживається з різною інтенсивністю: від легкої усмішки до гучного сміху, корелює, як уже зазначалось, з віком, емоційним досвідом і статтю (Изард, 2008: 146, 152-158, 165, 168).

Емотивні ситуації радості в емпіричному матеріалі поділяємо умовно на два типи: імпліцитні й експліцитні. Імпліцитне зображення стосується прихованого, непрямого вияву емоції радості персонажами або автором, експліцитне - з безпосереднім виявом емоційного стану радості або переживання.

Розглянемо ці типи емотивних ситуації більш докладно.

Ich drückte die Zigarette aus. Auf einmal dachte ich, vielleicht liebe ich in Uli nur etwas Vergangenes, halb Vergessenes, Kindheit, die mir die Erinnerung als ein Idyll vorgaukelt, und obgleich ich das Gaukelspiel durchschaute und hundert nüchterne Einwände habe, blicke ich mit einer Art sentimentalen Vergnügens auf den zuckenden Filmstreifen der Erinnerungen, auf diese Folge kolorierter Genrebildchen:

Blühende Kirschbäume im Garten, der Sandkasten, die roten und gelben blechernen Förmchen; eine mit Efeu bewachsene Mauer, an ihrem Fuß zwischen breitblättrigen, violett blühenden Klettenpflanzen sammeln wir Schneckenhäuser im feuchten, schwarzen Mulm; die Laube im Garten eines Spielkameraden, dessen Namen ich vergessen habe, wir hocken im Heu, spröder Duft, wir rauchen getrocknetes Weinlaub in kurzen indianischen Tonpfeifen; der Balkon, Julihitze, ein blauweiß gestreifter Sonnenschirm, die grünen Blumenkästen überwuchert von Petunien, es ist Mittag, wir warten auf unseren Vater, der mit dem Fahrrad aus seinem Verlag herüberkommt, wir kennen sein Klingelzeichen, wir winken und schreien; eine Zimmerstrecke in der Nachbarschaft, wo roh zusammengeschlagene Loren auf schmalen Schienen um den Holzplatz fahren, und es duftet süß und streng nach frischem Holz, wir spielen Trapper und Indianer und werfen mit Tomahawks; ein Winterabend, meine Mutter, rundlich und schwarzhaarig, sitzt im Korbsessel vor ihrem mahagonibraunen Nähtischchen und liest Andersens Märchen vor, hinter dem Fenster fällt die Dämmerung, es schneit ... (Reimann, 2007: 7-8). 
Тут емоцію радості виражено імпліцитно: Елізабет згадує 3 любов’ю про свого брата Ульріха, з яким вона зростала, гралася, бешкетувала, чекала на батька, проявляла ввічливість і демонструвала нестримний темперамент. Ї̈̈ стосунки з матір'ю суттєво відрізняються від стосунків із братом і батьком. Ідеться про трансформацію романтизму в 'жорстку' реальність, де метафорично панує, з одного боку, зима, темрява, таємничість, смерть, з другого - захист, гармонія, константність і водночас динамізм, сакральна могутність дерева та профана звуку. Елізабет підсвідомо хоче, щоб адресат не лише зрозумів іiі емоційний стан, але й відчув його, захопився ним і занурився в нього. Ці бажання відображено через яскраву образність локусів, зокрема квітучий вишневий садок Blühende Kirschbäume im Garten, місце між широколистими, з фіолетовим цвітом ліанами $z w i-$ schen breitblättrigen, violett blühenden Klettenpflanzen, альтанка $з$ духмяним сіном у сусідньому садку die Laube im Garten eines Spielkameraden, im Heu, spröder Duft, вологий, чорний грунт im feuchten, schwarzen Mulm, місце роботи батька aus seinem Verlag, робоче місце матері im Korbsessel, місце дії hinter dem Fenster, а також через обмежений простір: пісочниця Sandkasten, формочки Förmchen, черепашки равликів Schneckenhäuser, балкон Balkon, парасолька від сонця Sonnenschirm, ящики для квітів Blumenkästen; опозиційність часу: пік літа Julihitze, половина світлої доби Mittag, невизначений період зими й темний іï часовий відрізок ein Winterabend; широку палітру кольорів: 'теплих' rot, gelb, 'холодних' blauweiß, grün, schwarzhaarig, 'складних' koloriert, violett, mahagonibraun та наочність відчуттів: фізичних drückte die Zigarette aus, rauchen, warten auf, моторних sammeln, hocken, werfen mit Tomahawks, ментальних Auf einmal dachte, vielleicht liebe, Erinnerung als ein Idyll vorgaukelt, vergessen habe, сенсорних Gaukelspiel durchschaute, blicke auf, es duftet süß und streng nach frischem Holz, психічних sentimentalen Vergnügens, естетично-ментальних zuckenden Filmstreifen der Erinnerungen, естетичних gestreift, когнітивних wir kennen sein Klingelzeichen, культурних spielen Trapper und Indianer.

Привертає увагу розмитість суб'єкта емоції радості - 1-а особа однини Ich (1), ich (5), mir (1), meine (1) та його узагальнення - 1-а особа множини wir (7), багатоплановість джерел емоції радості: дитинство Kindheit, самостійні дитячі розваги sammeln wir Schneckenhäuser, wir hocken im Heu, wir rauchen, ігри wir spielen Trapper und Indianer und 
werfen mit Tomahawks, заняття wir warten auf unseren Vater, зустріч із батьком після роботи wir winken und schreien.

Маркерами емоції радості є словосполучення зі значенням особливостей психічного стану sentimentalen Vergnügens, розваги spielen Trapper und Indianer, Andersens Märchen, пари слів: а) дієслова зі значенням кінесики winken und schreien, б) прислівники зі значенням якості, міри й ступеня süß und streng, в) прикметники зі значенням якості rundlich und schwarzhaarig.

В експліцитній емотивній ситуації радості простежуємо час (відтинок доби, перший місяць літа, раніше), локус (залізничний парк, вігвам), ландшафт (парк, кущі), природні явища (вітер), міжособистісні стосунки за формулами 'дитина1 - дитина2', 'діти - дорослий', 'діти - батько', вияв емоційного стану радості дорослим 'незнайомцем’ і 'відомим' батьком: Eine Nacht im Juni: Wir warten im Bahnhofspark, die Büsche glänzen lackgrün unter einer im Wind schaukelnden Lampe. Ich halte Ulis Hand fest, als der dünne, schüchterne Mann auf uns zukommt. Er umarmt uns, über sein Gesicht laufen Tränen. Ein Fremder in zerlumpter Uniform, der beim Sprechen mit der Zunge anstößt; nun soll man also «Vater» zu ihm sagen - er hat aber nichts zu tun mit dem heiteren jungen Mann, der uns früher Schokoladezigarren mitbrachte und aus seinen Klubsesseln einen Wigwam für Winnetou und Mine-Haha baute (Reimann, 2007: 12).

У наведеному уривку суб'єкт - носій емоції радості - постає в двох іпостасях: як худий dünпе, сором'язливий, боязкий schüchterne чоловік Mann, незнайомець Fremder у обірваній військовій формі in zerlumpter Uniform, переповнений радістю від довгоочікуваної зустрічі з родиною Er umarmt uns, über sein Gesicht laufen Tränen, der beim Sprechen mit der Zunge anstößt та як невідомий, 'новий, 'інший' батько, емоційну поведінку якого дочка порівнює й оцінює в часі й просторі.

Ретроспективний погляд на емоцію радості очима героїні дає змогу виділити зміст, форму, характер, структуру, умови існування феномену (Кириленко, 2007: 19). Зміст емоції радості репрезентує зміну віку (батько став щонайменше на п'ять років старшим), розширення соціально-психологічного й емоційного досвіду (насильницька участь батька у війні, радянський полон, штрафні роботи, довга дорога додому, невідомість на батьківщині), потребу в контакті з дітьми, ширше родиною, інтерес до життя близьких і рідних, небайдуже, позитивне ставлення до них. Форма - емоційне 
переживання - детермінована впливом зовнішнього світу на суб’єкт. Характер відображення є виразно двоїстим, зокрема афективне хвилювання (обнімання дітей, уриване мовлення, експресивність під час гри з дітьми) й органічні вияви (сльози радості). У структурі реалізовано ідеальний і реальний чинники: ідеальний чинник - передчуття зустрічі з родиною, реальний - насолода від цієї зустрічі. Наведені чинники збігаються для суб'єкта емоції 'тут і тепер', є безсумнівним фактом, реальним свідченням про емоцію радості. Стосовно умови iii існування, то вона 'живе' в суб'єктові, активується ним відповідно до емотивної ситуації. Вияв емоції радості неконтрольований, стихійний, і це єднає особистість 'відомого, 'старого' батька з 'невідомим', 'новим' відповідно.

Механізм вияву емоції радості в 'старого' батька - його емоційна поведінка та альтруїзм Schokoladezigarren mitbrachte, aus seinen Klubsesseln einen Wigwam für Winnetou und Mine-Haha baute, в 'нового' кінестетичні сигнали (хода auf uns zukommt, міміка ӥber sein Gesicht laufen Tränen), дотики Er umarmt uns, просодика beim Sprechen mit der Zunge anstößt.

Джерелом емоції радості слугує двоє малолітніх дітей - хлопчик і дівчинка, пов'язаних із суб'єктом емоції радості кревними стосунками. Діти помітно виросли й хвилюються, чи впізнає їх батько через стільки років. Звичайно, батько впізнав дітей: у нього були світлини, які, очевидно, задовольняли потребу чоловіка в любові, близькості, радості. Світлини по праву можна вважати механізмом фізичного часу, що поєднує минуле, теперішнє й майбутнє або метафорично пронизує фрагменти історії сім'ї (позитив), насильницьку відірваність або відсторонення від родини (негатив) та плани, мрії про возз'єднання з нею (позитив).

Як бачимо, про походження цієї емоції радості ми можемо лише здогадуватись. На іï виникнення можуть впливати й індивідуальні особливості розвитку батька, зміна його статусу, ставлення до нього дітей, їхній емоційний стан тощо.

Маркером емоції радості є дієслова зі значенням дотику umarmt, просте розповідне речення зі значенням емоційного стану радості über sein Gesicht laufen Tränen, підрядне означальне речення зі значенням афекту der beim Sprechen mit der Zunge anstößt, емотивний прикметник heiter. 
Емоцію радості виражають через емоційні вигуки радості, звуки, спів, зміст пісні, повтор дії Er summte zwischen den Zähnen, ein eintöniges Kinderliedchen, zu dem wir auf der Straße gespielt hatten: «Dreht euch nicht um, der Plumpsack geht um, er geht um den Kreis, daß niemand es weiß. Dreht euch nicht um...» (Reimann, 2007: 96).

На передній план висувають емоційний стан суб’єктів за так званою 'нейтральною' формулою 'він Er - ми wir', образною 'він Plumpsack - ви euch', уявною 'він er - ніхто niemand', дію а) одноосібну summte, geht um (2), б) колективну gespielt hatten, якість об’єкта (носія емоційного стану) ein, eintöniges, об’єкт (емоційного стану) Kinderliedchen, ставлення групи дітей до об'єкта zu dem, місце дії auf der Straße, Kreis, спільні правила емоційної поведінки Dreht euch nicht um (2), обмеженість знань віртуального суб'єкта дії niemand es weiß.

Каузатор змальованої вище ситуації емоції радості - сімейна стара світлина з дітьми, що викликає в сестри спогади про надлишкову вагу брата Fettklößchen і його незграбність Plumpsack. Брат реагує на ці озвучені спогади - 'щире зізнання сестри' - мугиканням мелодії дитячої пісеньки. Тобто він захищається, приховує свій душевний біль, що зумовлює появу дистанціювання від сестри, родини, ширше батьківщини. Позитивна емотивна ситуація радості трансформується в негативну емотивну ситуацію ненависті: Er zeichnete mit einem Finger die nußbraune Maserung in dem schimmernden goldenen Holz nach; sein Gesicht war leer wie bei vielen Leuten, wenn sie sehr gesammelt nachdenken, und unvermittelt drehte er mir den Kopf zu mit einer Bewegung, in der sich Müdigkeit und Auflehnung mischten, und sagte den letzten Satz seines lautlosen Gesprächs mit mir oder mit sich selbst: «Und am meisten hasse ich euch dafür, daß ich mit schlechtem Gewissen weggehe. Das habt ihr geschafft. Irgendwie kriegt ihr alle soweit, oder fast alle ...»(Reimann, 2007: 96-97).

На тлі сказаного семантичний ланцюг перетворень емоції радості на почуття ненависті має такий вигляд: $\mathrm{Er} \rightarrow$ sein $\rightarrow$ seines $\rightarrow$ sich $\rightarrow$ ich. При цьому активну участь бере тіло, точніше його частини Finger, Gesicht, Kopf, фізичне навантаження мовленнєвих органів lautlosen Gesprächs, психіка mit selbst.

Механізмом зміни емоційного стану радості на емоційний стан ненависті є емотивна оцінка з лінійкою 'добре - погано'. Полюс 'добре’ відповідає як нормі, так і ії перевищенню, полюс «погано» «завжди означає відхилення від норми» (Приходько, 2016: 33). 
В аналізованому уривку простежуємо конфлікт між 'жертвою' і 'тираном'. 'Жертва' ich люто ненавидить 'свого тирана' euch, намагається зникнути з поля зору фізично, географічно, мріє про помсту й 'справедливість' Irgendwie kriegt ihr alle soweit, вірить почасти в реалізацію мрії oder fast alle.

Маркером негативної емотивної оцінки $є$ словосполучення зі значенням моралі schlechtem Gewissen. Для модифікації (підсилення) ефекту негативної оцінки використовують емоційне наростання через просте розповідне речення Das habt ihr geschafft та синтаксичну конструкцію з однорідними членами, пов'язаними сурядним засобом зв' язку Irgendwie kriegt ihr alle soweit, oder fast alle.

Варіантом емоції радості $є$ швидкоплинна емоція щастя, що переходить в емоцію суму: Ich war, heute, in diesem Augenblick, glücklich über das Bild: ein vorsichtiges Glück, das nicht lange anhielt; ich wußte aus Erfahrung, daß die Euphorie eines Arbeitsnachmittags schon am nächsten Morgen in trübe Unzufriedenheit umschlagen würde (Reimann, 2007: 124).

У наведеному прикладі тривалість емоції щастя обмежено не стільки знанням і досвідом Елізабет про емоцію wußte aus Erfahrung, скільки іiі стражданням через невизнання талановитості: Jetzt aber war ich noch befangen in einer naiven Freude an dem gemalten Mann (der mir morgen früh, wenn ich seinem lebendigen Vorbild begegnete, als eine beklagenswert unvollkommene Wiedergabe erschienen würde), ich war enttäuscht, weil Heiners kein Wort für meine Arbeit fand (там само). Як будь-який художник, дівчина мріє про славу, нагороду, заохочення, шанувальників. Коли ж відомий художник, комуніст Ом Гейнерс не висловив своєї авторитетної думки про роботу Елізабет kein Wort für meine Arbeit fand, вона була розчарована ich war enttäuscht.

У психології розчарування інтерпретують як «почуття незадоволеності, викликане нездійсненими чеканнями, надіями і мріями», як втрату «віри в когось, у щось» (Шадських, Піча, 2008: 185).

Отже, емоційний стан радості (щастя) залежить від визнання, оцінки, мотивації здобутків людини.

Зіставляючи текстове й словникове значення емотивної лексики, що позначає емоцію радості (WAHRIG, 2012; Мюллер, 2012), зауважимо, що левова частка лексем збігається з реєстровими одиницями, незначна їх кількість, а саме: складні слова Goldzahnlächeln і Zirkuslächeln не потрапила до реєстру (WAHRIG, 2012: 433, 1105; Мюллер, 2012: 
292, 728). Цікаво, що трикомпозит Goldzahnlächeln виражає поняття 'золотозуба усмішка', композит Zirkuslächeln - 'циркова усмішка'. Обидві лексеми функціонують у прямому й переносному значеннях. Пряме значення вказує на фізичний стан зубів (Goldzahnlächeln) та професійну поведінку в сфері розваг (Zirkuslächeln), переносне реалізує щирість, природність стосунків (Goldzahnlächeln) та офіційність, штучність (Zirkuslächeln) останніх. Зрозуміло, що текстовий портрет емоції радості неоднорідний, швидше комплексний, ніж системний, поєднує позитивний, нейтральний і негативний аспекти, зорієнтований на синтез художньої та соціально-психологічної реальності.

\section{Висновки}

Проведений аналіз показав, що емоція радості постає в річищі психічного та естетичного аспектів. Психічний аспект тотожний базовій позитивній емоції, естетичний - еквівалентний, з одного боку, вияву структурованої уяви, з другого - витвору художньої свідомості та параболічного, наративного мислення авторки (за Л. І. Бєлєховою, 2002). Як базова емоція радість залишається 'річчю в собі', як естетична апелює до когнітивних процесів, що використовує митець з метою художнього самовираження й естетичного впливу. Текстовий портрет емоції радості є результатом психічної та естетичної діяльності, грунтується на взаємодії емотивних ситуацій. Останні диференціюємо на два різновиди: імпліцитні й експліцитні. Їхнє смислове наповнення варіює від позитивного до нейтрального та негативного значення. Домінує імпліцитний різновид з позитивним значенням, що пояснюємо етнічним менталітетом і культурою поведінки. Носіїв емоції радості кваліфікуємо за кількома критеріями а) гендером (жінки, чоловіки), б) віком (молоді, літні), в) статусом (одружені, потенційно одружені (співмешканці), неодружені), д) емоційним станом (екстраверти, інтроверти), е) мовною компетенцією ('стилісти', 'граматисти', ширше 'філологи', 'лінгвісти’), є) комунікативною компетенцією (адресант, адресат), ж) культурною компетенцією (передбачувані (усталена або стереотипна поведінка), непередбачувані (неусталена або самобутня поведінка), з) формою спілкування (активні, пасивні). Причини появи емоції радості співвідносимо насамперед з ментальною (спогади) та психологічною (переживання, емоції, почуття, афекти) сферами індивідуума соціально-психологічними умовами (зустріч, робота, 
відпочинок), комунікативними актами (сім’я, друзі, товариші, знайомі, колеги, незнайомці, фахівці тощо). Стосовно втілення емоції радості засобами мовного коду, розрізняємо слово, словосполучення (вільне й стале), речення (просте, складне), власну назву.

В перспективі варто дослідити текстові портрети інших позитивних емоцій, як-от наприклад, інтересу, подиву або сорому та їхні основні функції в емотивних ситуаціях.

\section{ЛІТЕРАТУРА}

1. Белєхова, Л. І. (2002). Образний простір американської поезії: лінгвокогнітивний аспект. (Автореф. дис. ... докт. філол. наук). Київ: КНЛУ. 2. Гальперин, И. Р. (1981). Текст как объект тингвистического исследования. Москва: Наука. 3. Єщенко, Т. (2009). Сучасне розуміння тексту в лінгвістиці. Наук. вісн. Херсон. держ. ун-ту. Серія «Лінгвістика», 9, 9-12. 4. Изард, К. Э. (2008). Психология эмоций (В. Мисник, А. Татлыбаева, пер.). Санкт-Петербург: Питер. 5. Кириленко, Т. С. (2007). Психологія: емоційна сфера особистості. Київ: Либідь. 6. Лотман, М. Ю. (1998). Об искусстве: Структура художественного текста. Семиотика кино и проблемы киноэстетики. Статьи. Заметки. Выступления (1962-1993). Санкт-Петербург: Искусство-СПБ. 7. Мюллер, В. (2012). Великий німецько-український словник. Київ: Чумацький Шлях. 8. Орбан-Лембрик, Л. Е. (2004). Соціальна психологія. (Кн. 1: Соціальна психологія особистості і спілкування). Київ: Либідь. 9. Пентилюк, М. (2009). Текст: лінгвостилістичний аспект. Наук. вісн. Херсон. держ. ун-ту. Серія «Лінгвістика», 9, 37-42. 10. Приходько, Г. І. (2016). Категорія оцінки в контексті зміни лінгвістичних парадигм. Запоріжжя: Кругозір. 11. Романова, Н. В. (2020). Еліптичні речення як засіб вираження емоцій (на матеріалі оповідання Б. Рейман «Die Geschwister»). Лінгвістичні дослідження, 53, 105-116. 12. Филимонова, О. Е. (2007). Эмоциология текста. Анализ репрезентаиии эмоиий в английском тексте. Санкт-Петербург: ООО «Книжный Дом». 13. Шадських, Ю. Г., \& Піча, В. М. (2008). Психологія: короткий навчальний словник: терміни і поняттяя. Львів: Магнолія 2006. 14. Van Dijk, T. A. (1977). Text and context Explorations in the Semantics and Pragmatics of discourse. London; New York: Longman. 15. Reimann, B. (2007). Die Geschwister. Berlin: Aufbau Taschenbuch. 16. WAHRIG (2012). Wörterbuch der deutschen Sprache. München: dtv.

\section{REFERENCES}

1. Belekhova, L. I. (2002). Obraznyi prostir amerykanskoi poezii: linhvokohnityvnyi aspekt [Image Space of American Poetry: Cognitive Perspective]. Extended abstract of Doctor's thesis. Kyiv: KNLU [in Ukrainian]. 2. Galperin, I. R. (1981). Tekst kak obekt lingvisticheskogo issledovaniia [Text as object of linguistic research]. Moskva: Nauka [in Russian]. 3. Eschenko, T. (2009). Suchasne pozuminnia tekstu v linhvistytsi [Modern understanding of Text in Linguistics]. Nauk. visn. Kherson. derzh. un-tu. Seriia "Linhvistyka" - Scientific Journal of Kherson State University. Series "Linguistics", 9, 9-12 [in Ukrainian]. 4. Izard, C. E. (2008). Psikhologiia emotsii [Psychology of Emotions] (V. Misnik, A. Tatlybaeva, trans.). Sankt-Petersburg: Pieter [in Russian]. 5. Kyrylenko, T. S. (2007). Psykholohiia: emotsiina sfera osobystosti [Psychology: Emotional Sphere of Personality]. Kyiv: Lybid [in 
Ukrainian]. 6. Lotman, M. Yu. (1998). Ob iskusstve: Struktura khudozhestvennogo teksta. Semiotika kino I problemy kinoestetiki. Stati. Zametki. Vystupleniia (1962-1993) [About the Art: Structure of the Texts of the Art. Semiotic of Films, and Problems of Film Aesthetics. Articles. Notes. Speeches (1962-1993)]. Sankt-Petersburg: Iskusstvo-SPB [in Russian]. 7. Myuller, V. (2012). Velykyi nimetsko-ukrainskyi slovnyk [Big German-Ukrainian Dictionary]. Kyiv: Chumatskyi Shliakh [in German-Ukrainian]. 8. Orban-Lembryk, L. E. (2004). Sotsialna psykholohiia [Social Psychology]. (Vol. 1). Kyiv: Lybid [in Ukrainian]. 9. Pentylyuk, M. (2009). Tekst: linhvistychnyi aspekt [Text: linguistic aspect]. Nauk. visn. Kherson. derzh. un-tu. Seriia "Linhvistyka" - Scientific Journal of Kherson State University. Series "Linguistics", 9, 37-42 [in Ukrainian]. 10. Prykhodko, H. I. (2016). Katehoriia otsinky v konteksti zminy linhvistychnykh paradyhm [Category of Valuation in context of Change of Linguistic Paradigms]. Zaporizhzhia: Kruhozir [in Ukrainian]. 11. Romanova, N. V. (2020). Eliptychni rechennia iak zasib vyrazhennia emotsii (na materiali opovidannia B. Reiman "Die Geschwister" [Elliptic Sentences as a Means of Expression od Emotions (Based on B. Reimann's Story "Die Geschwister"]. Linhvistychni doslidzhennia - Linguistic research, 53, 105-116. https://doi.1 0.34142/23127546.2020.53.10 [in Ukrainian]. 12. Filimonova, O. E. (2007). Emotsiologiia teksta. Analiz reprezentatsii emotsii v angliiskom iazyke [Emotionality of the Text. Anatomy of Representation of the Emotions in the English text]. Sankt-Petersburg: OOO "Knizhnyi Dom" [in Russian]. 13. Shadskykh, Yu. H., \& Picha, V. M. (2008). Psikholohiia: Korotkyi navchalnyi slovnyk: terminy i poniattia [Psychology: a Short teaching Dictionary: Terms and Concepts]. Lviv: Mahnoliia 2006 [in Ukrainian]. 14. Van Dijk, T. A. (1977). Text and context Explorations in the Semantics and Pragmatics of discourse. London; New York: Longman [in English]. 15. Reimann, B. (2007). Die Geschwister [The siblings]. Berlin: Aufbau Taschenbuch [in German]. 16. WAHRIG (2012). Wörterbuch der deutschen Sprache [German language dictionary]. München: dtv [in German].

Романова Наталя Василівна - доктор філологічних наук, доцент, професор кафедри німецької та романської філології, Херсонський державний університет; вул. Університетська, 27, м. Херсон, 73000, Україна.

Tel.: +38-066-55-72-417

E-mail: vissensvelt@gmail.com

http://orcid.org/0000-0002-7444-3811

Romanova Natalia Vasylivna - Doctor of Philological Sciences, Docent, Professor at the Department of German and Romance Philology, Kherson State University; 27 Universytetska Str., Kherson, 73000, Ukraine.

\section{CITATION}

Надійшла до редакції 18 січня 2021 року

ДСТУ 8302:2015: Романова Н. В. Текстовий портрет емоції радості (на матеріалі оповідання Б. Рейман «Die Geschwister»). Лінгвістичні дослідження: зб. наук. пр. Харк. нац. пед. ун-ту імені Г. С. Сковороди. Харків, 2021. Вип. 54. Ч. І. С. 120-131. DOI: https://doi.org/10.34142/23127546.2021.54.1.10

APA: Романова, Н. В. (2021). Текстовий портрет емоції радості (на матеріалі оповідання Б. Рейман «Die Geschwister»). Лінгвістичні дослідження, 54 (I), 120-131. DOI: https://doi.org/10.34142/23127546.2021.54.1.10 